\title{
May the crossing between diploid and tetraploid Italian ryegrass transfer glyphosate resistance to the next generation?
}

\author{
Maicon Fernando Schmitz ${ }^{1}$ (D), Joanei Cechin",* (D), Andrés Antonio Monge Vargas ${ }^{3}$ (D), Jonas \\ Rodrigo Henckes $^{4}$ (D), Leandro Vargas ${ }^{5}$ (D), Dirceu Agostinetto ${ }^{1}$ (D), Beatriz Helena Gomes Rocha ${ }^{6}$ (D), \\ Vera Lucia Bobrowski ${ }^{6}$ (D) \\ 1. Universidade Federal de Pelotas - Departamento de Fitossanidade - Capão do Leão (RS), Brazil. \\ 2. Universidade Estadual de Ponta Grossa - Departamento de Fitotecnia e Fitossanidade - Ponta Grossa (PR), Brazil. \\ 3. Universidade Federal de Pelotas - Departamento de Fitotecnia - Capão do Leão (RS), Brazil. \\ 4. Universidade Estadual de Maringá - Departamento de Agronomia - Maringá (PR), Brazil. \\ 5. Empresa Brasileira de Pesquisa Agropecuária - Departamento de Plantas Daninhas - Passo Fundo (RS), Brazil. \\ 6. Universidade Federal de Pelotas - Departamento de Biologia - Capão do Leão (RS), Brazil.
}

\begin{abstract}
Italian ryegrass (Lolium multiflorum Lam.) is a grass weed found in winter cereals, with several glyphosate-resistant diploid populations. Furthermore, the use of Italian ryegrass tetraploid genotypes creates an opportunity to increase the forage demand in replacement of diploid populations. The aim of this research was to evaluate the crossing capacity between glyphosate-resistant diploid and tetraploid Italian ryegrass to transfer glyphosate resistance to the next generation. Reciprocal crosses were performed using the susceptible tetraploid cultivar INIA Titan and resistant diploid (SVA04 biotype) plants to obtain the F1 progeny. Germination testing, survival percentage, inheritance of glyphosate-resistance, and ploidy level were evaluated in F1 progeny. Crossing of susceptible tetraploid plants $\hat{\partial}$ and glyphosateresistant diploid $q$ affected the germination and exhibited $4.5 \%$ of triploid plants. F1 progeny from the glyphosate-resistant diploid $\widehat{\partial}$ and susceptible tetraploid $q$ did not show germination problems, but $46 \%$ of the plants died during the initial seedling stage. For this progeny, 10 and $25 \%$ of the seedlings were composed of triploid and pentaploid individuals, respectively. Crosses between susceptible tetraploid $q$ and resistant diploid $\hat{\partial}$ did not transfer the glyphosateresistant for the plants. Susceptible tetraploid $\hat{o}$ crossing with diploid resistant $q$ had $a$ reduction of $47 \%$ the glyphosate-resistant plants compared to the homozygous glyphosateresistant progeny. Overall, tetraploid Italian ryegrass can be a safe tool to reduce and manage the increase of glyphosate-resistant diploid ryegrass in field conditions.
\end{abstract}

Key words: Lolium multiflorum Lam., ploidy level, chromosome counting, resistance.
Received:

Dec, 12, 2019

Accepted:

Apr. 14, 2020

Section Editor:

Alberto Cargnelutti Filho

${ }^{*}$ Corresponding author: joaneicechin@yahoo.com.br

\section{INTRODUCTION}

Italian ryegrass (Lolium multiflorum Lam.) is a troublesome winter annual grass found in agricultural systems cultivated with wheat and barley, and widely used as forage to animal feed and soil cover plant (Vargas et al. 2016). In the last years, the area cultivated with tetraploid Italian ryegrass has been increasing in the Southern Brazilian fields due to the occurrence of diploid glyphosate-resistant populations, and its characteristics such as higher yield of pasture and nutritive value compared to diploid plants (Oliveira et al. 2014). Currently, diploid glyphosate-resistant populations of Italian ryegrass can be found 
in approximately 6.03 million $\cdot$ ha $^{-1}$, a critical scenario for management in cultivated fields in which the glyphosate herbicide has been frequently used, with cases of up to four applications in the same cultivation area (Lucio et al. 2019).

Genome duplication is a natural phenomenon characterized by the presence of more than two chromosomal sets in the cells, characteristic present in some organisms and an important driving force to the survival and evolution of the plants throughout generations, considered a strategy essential for the faster increase of ecological dominance (Adams and Wendel 2005; Wendel et al. 2016; Roodt et al. 2017). In contrast, artificial genome multiplication by antimitotic compounds can be used for breeding programs in forage species and lead to stable genomic states (Pereira et al. 2012). The technique allows increasing the expression of interest agronomic characteristics, restoring the fertility of intra- and interspecific hybrids and, in some cases, used to the exploration of genetic variability in apomictic species. Besides, the technique can be used to induce the genome duplication in plants, allowing combinates ploidy between crosses and obtain fertile progeny (Timbó et al. 2014; Pereira et al. 2017). For the tetraploid Italian ryegrass, polyploidy induction increased the palatability and forage digestibility as result of the greater amount of soluble sugars and lower stem/leaf ratio (Nair 2004). Furthermore, tetraploid plants have faster initial growth rate, greater tillers number, higher forage production, and longer vegetative period compared to the diploid Italian ryegrass plants, important characteristics to growth and rapid establishment in agricultural systems (Tonetto et al. 2011; Schmitz et al. 2019).

In addition, tetraploid Italian ryegrass cultivars $(2 \mathrm{n}=4 \mathrm{x}=28$ chromosomes) may interact naturally with diploid populations ( $2 \mathrm{n}=2 \mathrm{x}=14$ chromosomes) in free-environmental, in which the presence of herbicide-resistant Italian ryegrass diploid populations can transfer the resistance to tetraploid genotypes by pollen exchange during the pollination. For example, crossing between diploid and tetraploid of perennial ryegrass (Lolium perenne L.) plants produced seeds with reduced germination due to the occurrence of triploid plants and their negative effects from meiosis with unequal segregation of the chromosomes (Ranney 2006). However, introgression of phenoxy herbicide resistance from radish (Raphanus raphanistrum L.) into fodder radish (Raphanus sativus L.) produced resistant F1 progeny (Jugulam et al. 2014).

Gene flow from diploid resistant-populations to susceptible tetraploid plants by pollen movement allows carrying herbicide-resistant alleles, especially in weed with cross-pollination and nuclear herbicide-resistance of complete or incomplete dominance inheritance. Thus, increasing of herbicide resistance and plant survival can occur exponentially in several populations (Ghanizadeh et al. 2019). Our hypothesis is based for the sowing of tetraploid Italian ryegrass in fields with resistant diploid populations as a tool to reduce future infestations of diploid glyphosate-resistant populations, a scenario with the absence of approaches about the crossing capacity between diploid and tetraploid Italian ryegrass plants occurs without the resistance alleles transference. Therefore, the aim of this research was to evaluate the crossing capacity between glyphosate-resistant diploid and tetraploid Italian ryegrass to transfer glyphosate resistance to the next generation.

\section{MATERIAL AND METHODS}

\section{Plant material}

A total of 25 seedlings from five glyphosate-resistant diploid Italian ryegrass plants (SVA04 biotype) harvested in São Valentin-RS, previously characterized with nontarget site resistance (Vargas et al. 2016), were transplanted separately in trays containing soil and substrate in a 3:1 proportion. Glyphosate herbicide (Glifosato Atanor 48) at a rate of $2160 \mathrm{~g}$ a.e. $\mathrm{ha}^{-1}$ was applied at the beginning tillering stage to confirm the herbicide-resistance. The application was performed with a $\mathrm{CO}_{2}$ backpack sprayer, fitted with four TeeJet TTi 110.15 nozzles and calibrated to deliver $120 \mathrm{~L} \cdot \mathrm{ha}^{-1}$. Before of glyphosate application, a tiller from each mother-plant from a total of 25 was transferred to a new tray, and used posteriorly to the crosses. Only the tillers that survived the application of the previously selected glyphosate from mother plants on the crosses were used. This prerequisite was used to confirm the biotype homozygosis to glyphosate resistance, using individuals with the same genetic condition inherited of parental (Vargas et al. 2007). Also, the tetraploid cultivar ('INIA Titan') was used as homozygous to glyphosate susceptibility. 
Plant growth and crosses between resistant-diploid (SVA04) and susceptible-tetraploid ('INIA Titan') plants were performed in isolated and sealed growth chambers to avoid external pollen contamination, with day/night temperature of $28 / 20 \pm 3{ }^{\circ} \mathrm{C}$ and relative air humidity around $65 \%$. Thus, the progeny obtained was pollinated only with pollen from their parental pairs. The separate plants were used to the crossings performed between glyphosate-resistant diploid (DRRㅇ $\left.\times \mathrm{DRR}^{\lambda}\right)$,

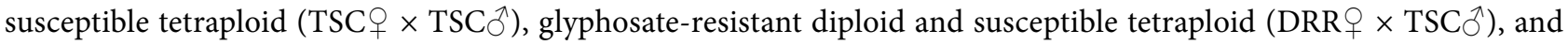
glyphosate-resistant diploid and susceptible tetraploid (DRR ${ }^{\lambda} \times \mathrm{TSC}_{+}$) using a completely randomized experimental design with five repetitions.

The reciprocal crosses were manually performed by shaking the plants three times a day to pollen spreading during pollination and received an adequate pollen amount from its genitor. Individual plants of each genitor were placed in plastic pots with $8 \mathrm{~L}$ of volumetric capacity, containing soil and GerminaPlant commercial substrate in a 3:1 proportion. The soil was classified as Endoaquult (according to the USDA Soil Taxonomy) with a sandy-loam texture and 1.5\% organic matter. Fertilization was performed before the transplanting, using $250 \mathrm{~kg} \cdot \mathrm{ha}^{-1}$ from a mixture of 05-20-20 NPK fertilizer, and nitrogen supplemented with urea at a rate of $120 \mathrm{~kg} \cdot \mathrm{ha}^{-1}$ at the beginning tillering phenological stage.

The F1 offspring obtained from the crosses with five replicates were $\mathrm{DRR} \hat{\jmath} \times \mathrm{DRR} q, \mathrm{TSC} \hat{0} \times \mathrm{TSC} q, \mathrm{DRR}+\times \mathrm{TSC} \hat{\jmath}$, DRR $\hat{O} \times$ TSC + . Full seeds harvested from female plant (ㅇ) of each crossing were manually selected in a light diaphanoscope and stored at $10{ }^{\circ} \mathrm{C}$ for five months to break dormancy and perform the experiments described below.

\section{Seed germination and viability}

Germination and seed viability tests were carried out at Seed Laboratory the Federal University of Pelotas, using 50 seeds from the crosses (F1 progeny) and four repetitions each. Seeds were placed in transparent plastic boxes $(11 \times 11 \times 2.5 \mathrm{~cm})$ on two layers of white blotter paper moistened with distilled water equivalent to 2.5 -fold the weight paper. The boxes were distributed in a completely randomized design into a biological oxygen demand (BOD) chamber at $30^{\circ} \mathrm{C} /$ light $(8 \mathrm{~h})$ and $20^{\circ} \mathrm{C} /$ dark ( $16 \mathrm{~h}$ ). Germination (G) was evaluated at five (first count) and 14 days after sowing (DAS). Additionally, abnormal seedlings (AS), dead seeds (DS) and nongerminated seeds (NGS) were evaluated at 14 DAS, according to the rules for seed testing (Brazil 2009). Viability of nongerminated seeds was assessed using a 1\% tetrazolium solution (2,3,5-triphenyltetrazolium chloride), in which the seeds were longitudinally cut-off from the embryo. The seeds in tetrazolium solution were maintained for $24 \mathrm{~h}$ in the dark at $30 \pm 2{ }^{\circ} \mathrm{C}$ (Brazil 2009). Viable seeds showed the embryo stained in pink or carmine color, whereas the absence of color were nonviable seeds.

Data of germination, abnormal seedlings and dead seeds, viable and nonviable seeds were expressed in percentage values, and assessed of normality by the Shapiro-Wilk test. The analysis of variance $(\mathrm{p}<0.05)$ was performed and, the means of the treatments were compared by Tukey's test $(\mathrm{p}<0.05)$.

\section{Seedling survival and glyphosate resistance inheritance}

Survival and glyphosate inheritance tests were carried out in a greenhouse under controlled conditions, using normal seedlings from the first count evaluated in the germination testing. These seedlings were transplanted into trays, containing soil and substrate in a 3:1 proportion. The experiment was performed in a completely randomized experimental design, using 25 seedlings with five biological replicates and four analytical repetitions, totalizing 500 seedlings by crossing. In specific cases, in which the crosses showed low seed viability, all germinated seedlings were transplanted.

Survival percentage was evaluated at the beginning tillering phenological stage before glyphosate application, counting the seedlings number that survived to the transplant. Glyphosate resistance inheritance was confirmed after spraying of 2160 g a.e. ha $^{-1}$ (Glifosato Atanor 48), using a $\mathrm{CO}_{2}$ backpack sprayer with TeeJet TTi 110.15 nozzles and calibrated to deliver $120 \mathrm{~L} \cdot \mathrm{ha}^{-1}$. Percentage control performed at 21 days after application (DAA) was used to determine the glyphosate resistance inheritance, considering the plant numbers of each crossing that died or survival.

Data were analyzed for normality by Shapiro-Wilk test, and submitted to the analysis of variance $(\mathrm{p}<0.05)$. The means were compared by Tukey's test $(\mathrm{p}<0.05)$. 


\section{Chromosome counting}

Chromosome counting was performed in the Genetics Laboratory at the Federal University of Pelotas, using roots with $1.5 \mathrm{~cm}$ of length, soaked in a $0.002 \mathrm{~mol} \cdot \mathrm{L}^{-1}$ solution of 8 -hydroxyquinoline (8-HQ) for $24 \mathrm{~h}$ at $4{ }^{\circ} \mathrm{C}$. The material was fixed in Carnoy's fixative I (3:1 ratio of absolute alcohol and glacial acetic acid) at room temperature for $24 \mathrm{~h}$, and stored on Carnoy's fixative I at $4-6{ }^{\circ} \mathrm{C}$ until microscope slides preparation. Seedlings were washed three-fold with distilled water to remove the fixative agent, and hydrolyzed in a $5 \mathrm{~N} \mathrm{HCl}$ solution for $20 \mathrm{~min}$ at room temperature to prepare the slides. After hydrolysis, triple washing was performed again, but only the root apical meristem was removed from the seedling, with the aid of a magnifying glass and histological needles. Root apical meristems were crushed on a microscope slide with a drop of $2 \%$ acetic orcein dye. For microscopic analysis, the material was covered with a coverslip, briefly heated on a flame and squeezed with a micro-press. Chromosome counting was performed on 10 microscope slides during the visible metaphases for each biological replicate, totaling 50 slides by crossing. For repetitions with germination lower than 10 seedlings, the counting was performed in accordance with the available material.

\section{RESULTS AND DISCUSSION}

\section{Seed germination and viability}

Italian ryegrass crosses occurred successfully from seeds produced by crosses with the same ploidy level, resulting in

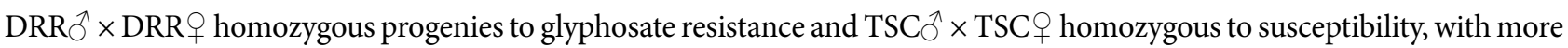
than $70 \%$ of germination at 14 DAS (Table 1). Seeds from the DRR $q \times$ TSC $\widehat{A}$ progeny exhibited low germination, with only $6 \%$ at 14 DAS. These results indicate that seeds from diploid plants pollinated by the tetraploid genotype are not viable; although low germination can occur due to the small self-fertilization ratio reported for this species (Fearon et al. 1983).

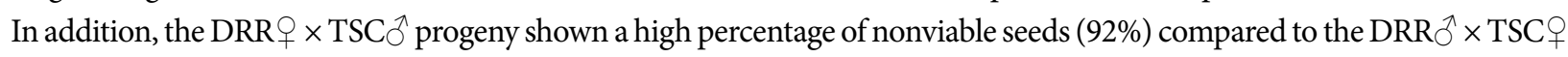
progeny, whereas these crosses had no germination problem, with values similar to the offspring obtained from crossing between TSC $\hat{0} \times \operatorname{TSC}_{+}$(Table 1). Similar results were found to crosses of diploid perennial ryegrass with tetraploid hybrids, in which the seeds produced in diploid plants had seedlings with germination less than $1 \%$, resulting in the failure of endosperm biosynthesis to trigger the embryo survival and seed germination (Ahloowalia 1975). Similar behavior was found in watermelon (Citrullus lanatus) with the production of viable seeds only to crosses between tetraploid $q$ and diploid $\delta$ plants, whereas the crossing of diploid $Q$ and tetraploid $\widehat{ }{ }^{\lambda}$ plants did not lead to fertilization (Medina et al. 1958).

Seed formation to the crosses between diploid plants involves the embryo growth after fertilization which contains the same contribution of maternal and paternal genome. The formed endosperm is also a fertilization product, but its triploid and contains one paternal and two maternal genome equivalents, with the single-cell layer presence depending on species.

Table 1. Seed germination at five and 14 days after sowing (DAS), abnormal seedlings, dead, viable and nonviable seeds of Italian ryegrass genotypes involving ploidy levels and glyphosate-resistant diploid genotype.

\begin{tabular}{|c|c|c|c|c|c|}
\hline \multirow{2}{*}{ Crosses } & \multicolumn{2}{|c|}{ *\% germination } & \multirow{2}{*}{$\begin{array}{c}\text { \% abnormal } \\
\text { seedlings }\end{array}$} & \multicolumn{2}{|c|}{$\%$ seeds } \\
\hline & 5 DAS & 14 DAS & & Viable & Nonviable \\
\hline $\mathrm{DRR}_{0}^{\lambda} \times \mathrm{DRR}_{+}$ & $63 b^{*}$ & $70 \mathrm{~b}$ & $2.0^{\mathrm{ns}}$ & $78 a$ & $22 \mathrm{~b}$ \\
\hline $\operatorname{TSC}_{0}^{\lambda} \times \operatorname{TSC}_{+}$ & $84 a$ & $88 a$ & 1.0 & $89 a$ & $11 a$ \\
\hline $\operatorname{DRR}_{+} \times \operatorname{TSC}^{\lambda}$ & $5.0 \mathrm{c}$ & $6.0 \mathrm{c}$ & 1.0 & $8.0 \mathrm{~b}$ & $92 \mathrm{a}$ \\
\hline $\mathrm{DRR}^{\lambda} \times \mathrm{TSC}_{+}$ & $86 a$ & $88 a$ & 1.0 & $89 a$ & $11 a$ \\
\hline CV (\%) & 16.7 & 13.6 & 105.6 & 11.84 & 21.84 \\
\hline
\end{tabular}

${ }^{*}$ Means followed by the same letter in the column do not differ by Tukey's test $(p<0.05)$. ns Nonsignificant. DRR: glyphosate resistant diploid genotype, TSC: glyphosate susceptible genotype. $\delta$ : male genitor,, : female genitor. CV: coefficient of variation. 
On the other hand, diploid seed coat contains only maternal tissue (Van Zanten et al. 2013). Thus, theoretically, the progeny

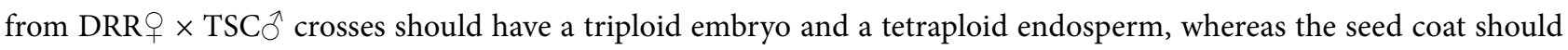
be diploid. However, high seed number without embryo ( $92 \%$ value) was found by the seed viability test (Table 1, Fig. 1). The incompatibility of chromosomal sets to form the embryo in $\mathrm{DRR}+\times \mathrm{TSC}^{\lambda}$ crosses can contribute strongly to the high percentage of nonviable seeds (Ruchel et al. 2015). Another possibility involves errors during the meiosis in diploid plants, in which the chromosomes fail to properly segregate to daughter cells. Thus, the unreduced gamete can unite with a haploid gamete, resulting in a triploid zygote that can originate a triploid plant. Sterile triploid plants were found to the crosses of diploid and tetraploid Centaurea seridis L. plants, which had chromosomes failure to pair correctly during the meiosis and provided a reproductive barrier (Ferriol et al. 2015). However, our results demonstrate only $4.5 \%$ of triploid plants to the

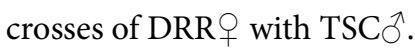
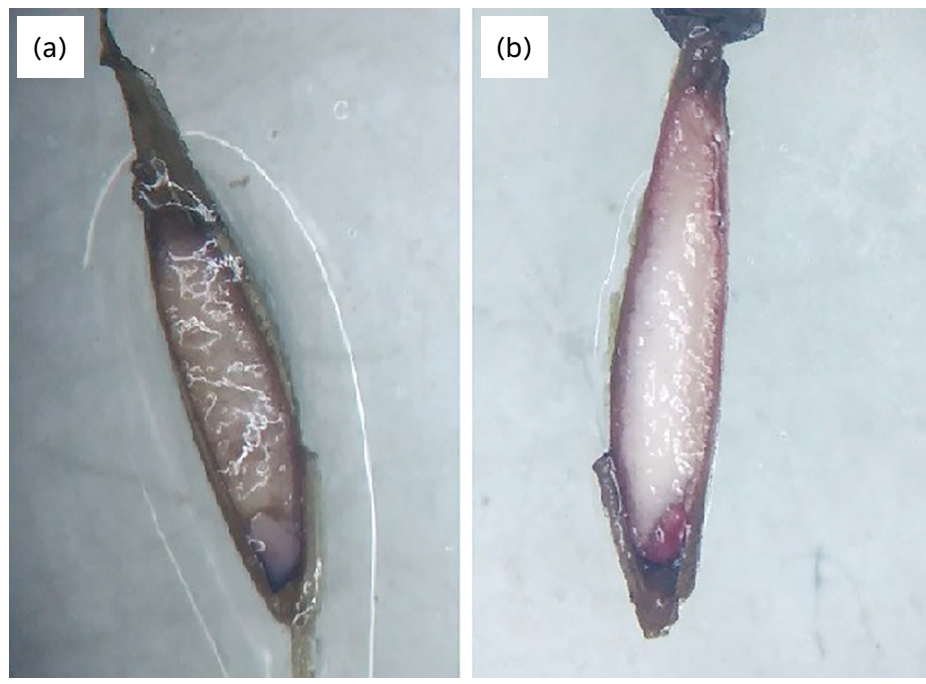

Figure 1. Italian ryegrass seeds from the crossing between DRR $\propto \times \operatorname{TSC} \widehat{\partial}$, without embryo (a) and normal embryo (b) after exposure to 2-3-5 triphenyl tetrazolium chloride salt (1.0\%) for $24 \mathrm{~h}$.

\section{Seedling survival and inheritance of glyphosate resistance}

The progeny from DRR $\widehat{O} \times$ TSC $q$ crossing showed a low survival ratio, with $46 \%$ of transplanted seedlings death before glyphosate application (Table 2). Similar results were found for crosses of diploid and tetraploid ryegrass, in which the seeds showed germination problems or death of seedlings soon after germination (Bustamante et al. 2015). However, the authors did not explain if the seeds produced by female diploid and male tetraploid parents were mixed or not. In this research,

Table 2. Survival percentage of Italian ryegrass progenies at the six-leaf stage before glyphosate application, and percentage of susceptible and resistant plants evaluated after glyphosate application in crosses involving different ploidy levels and glyphosate-resistant diploid genotype.

\begin{tabular}{|c|c|c|c|c|}
\hline \multirow{2}{*}{ Crosses } & \multirow{2}{*}{$\begin{array}{c}\text { Plants } \\
\text { evaluated }\end{array}$} & \multirow{2}{*}{$\begin{array}{c}\text { Survival } \\
\text { (\%) }\end{array}$} & \multicolumn{2}{|c|}{ Plants (\%) } \\
\hline & & & Susceptible & Resistant \\
\hline $\operatorname{DRR}_{\widehat{N}}^{\lambda} \times \mathrm{DRR}_{+}$ & 500 & $80 b^{\star}$ & $28 \mathrm{c}$ & $72 a$ \\
\hline $\operatorname{TSC}_{0} \hat{x} \times \operatorname{TSC}_{+}$ & 500 & $96 a$ & $100 a$ & $0 \mathrm{c}$ \\
\hline $\operatorname{DRR}_{+} \times \operatorname{TSC}^{\lambda}$ & 52 & $86 a b$ & $68 \mathrm{~b}$ & $32 b$ \\
\hline $\mathrm{DRR}_{0} \hat{\times} \times \mathrm{TSC}_{+}$ & 500 & $54 \mathrm{c}$ & $100 \mathrm{a}$ & $0 \mathrm{c}$ \\
\hline $\mathrm{CV}(\%)$ & - & 7.94 & 8.74 & 25.23 \\
\hline
\end{tabular}

${ }^{*}$ Means followed by the same letter in the column do not differ by Tukey's test $(p<0.05)$. DRR: glyphosate resistant diploid genotype, TSC: glyphosate susceptible genotype. ${ }^{*}$ : male genitor,, : female genitor. CV: coefficient of variation. 
the harvest of seeds from diploid parents crossed with tetraploid plants was performed separately, in which germination problems were found only for the seeds produced by the female diploid parent. Seeds produced by the tetraploid female parent had survival problems in the seedlings stage.

Modification of ploidy levels may lead to extensive changes on gene expression in response to silencing, retention, loss of duplicated genes, functional diversification and subfunctionality (Adams and Wendel 2005). After germination, seedlings need to activate and control a lot of genes to grow up and become photoautotrophic and independent of endosperm storage (Van Zanten et al. 2013). Thus, extreme changes in gene expression during this period can cause problems to seedlings with the duplicate genome, affects the gene expression regulation and losses of functional genes (Adams and Wendel 2005; Van Zanten et al. 2013). Seedling mortality from $\mathrm{DRR}_{\hat{O}}^{\hat{\gamma}} \times \mathrm{TSC}_{q}$ progeny can probably be triggered as a result of different ploidy level from their genitors, in which the interference of gene regulation and expression lead to the loss of essential functional genes needed to growth and survival (Table 2).

Evaluating the glyphosate resistance inheritance, no glyphosate-resistant plants were identified for TSC $\hat{\jmath} \times \operatorname{TSC}_{q}$ and DRR ${ }^{\lambda} \times$ TSC + progenies (Table 2, Fig. 2). In Italian ryegrass, glyphosate-resistance is encoded by a nuclear semidominant gene and can be disseminated to susceptible populations by pollen (Ghanizadeh and Harrington 2018). However, all $\mathrm{DRR}_{\partial} \times \mathrm{TSC}+$ progenies were susceptible to glyphosate herbicide when the glyphosate-resistant diploid plants were pollinated by susceptible tetraploids. Additionally, gene transfer may be complex due to variation in chromosome numbers in some cases, such as reported in Brassicaceae family which the crosses can produce nonfertile hybrids, but F1 progeny from the seeds harvested of crossing between resistant radish with susceptible fodder radish showed resistance to MCPA herbicide applied at rates up to $750 \mathrm{~g}$ a.e. ha ${ }^{-1}$ (Jugulam et al. 2014).

These results may be explained by three major hypotheses: the first evidence refers to fertilization involving different ploidy levels; therefore, the genome may be unable to express essential genes to primary metabolism of plants, triggering death after the initial seedling development stage (Adams and Wendel 2005). The second hypothesis involves the fertilization process, which may have led to losses of duplicate genes, functional diversification, and subfunctionality (Adams and Wendel 2005), without the gene expression of glyphosate-resistance alleles. Finally, susceptible glyphosate plants can be originated from self-fertilization from crossing between diploid and tetraploid genitors (Fearon et al. 1983). Although
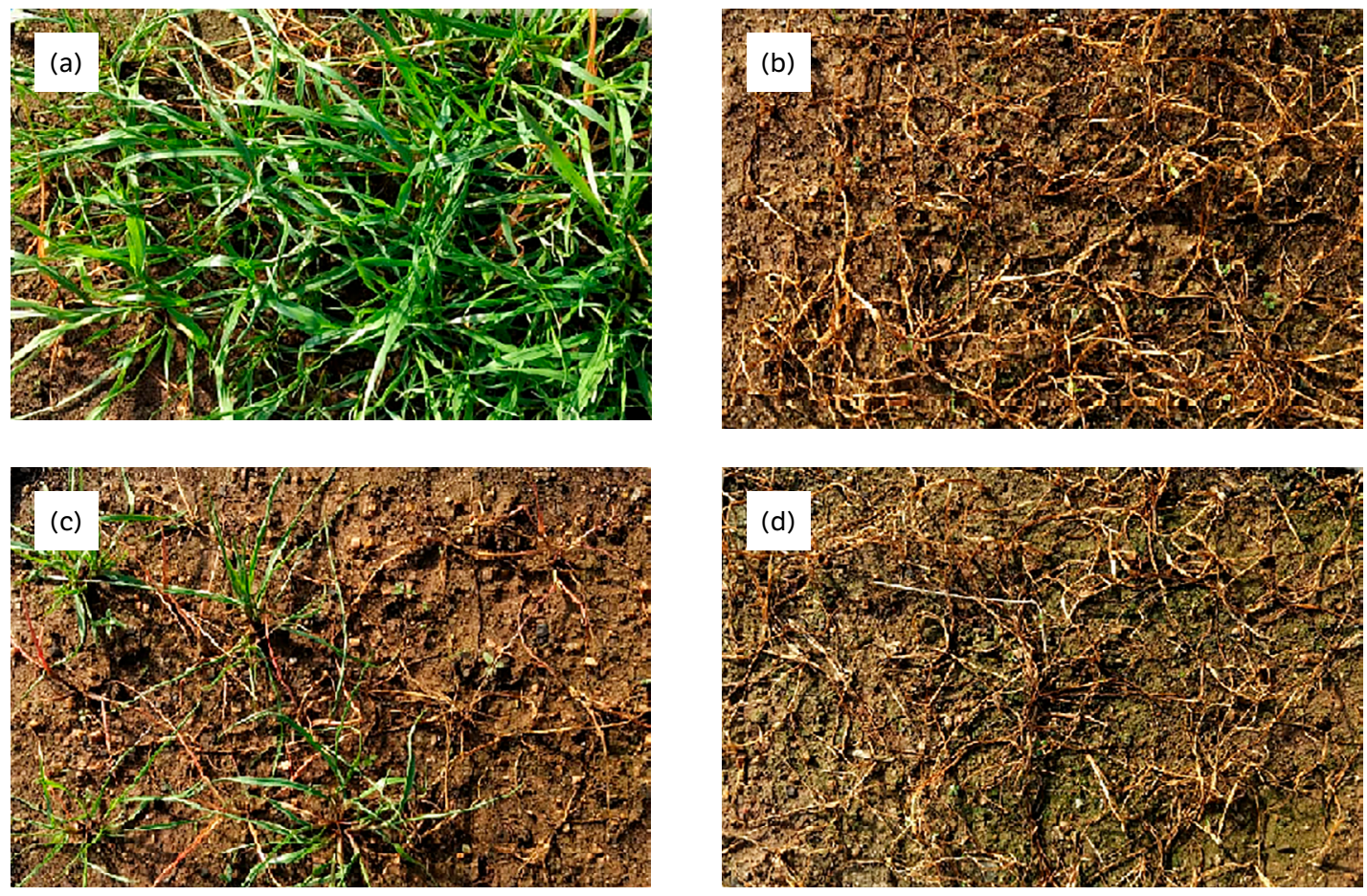

Figure 2. Glyphosate control of the offspring from crosses among glyphosate-resistant diploid and susceptible tetraploid Italian ryegrass.

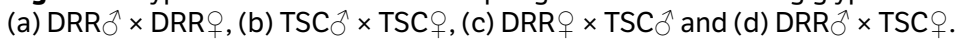


the DRR $\widehat{O} \times$ DRR $q$ crosses had been considered homozygous to the resistance, $28 \%$ of the plants died after glyphosate application (Table 2, Fig. 2). In this case, glyphosate-resistance of Italian ryegrass can be explained by alleles with incomplete dominance and segregation of a 3:1 ratio (Vargas et al. 2007). Thus, the phenotype of heterozygous individuals can be intermediate between homozygous parent phenotypes, in which each plant may show a different response to herbicide compared to their resistant parents. Similar behavior was reported for Italian ryegrass plants submitted to $2,160 \mathrm{~g}$ a.e. ha $^{-1}$ of glyphosate, with control of $60 \%$ at 45 days after application, even in plants resulting from the crossing between resistant biotypes (Vargas et al. 2007).

In tetraploid plants pollinated with glyphosate-resistant diploids ( $\mathrm{DRR}+\times \mathrm{TSC}^{\lambda} \mathrm{cross}$ ), the progeny showed a reduction of $47 \%$ of resistant plants compared to the glyphosate-resistant homozygous DRR $\hat{O} \times$ DRR $q$ progeny (Table 2, Fig. 2). The results presented in this study on glyphosate-resistance inheritance in tetraploid Italian ryegrass involving ploidy levels demonstrate that the use of tetraploid genotypes can be a safe tool to reduce or avoid the increase of glyphosate-resistant diploid populations in cultivated fields with resistance problems.

\section{Chromosome counting}

DRR $\hat{O} \times \mathrm{DRR}_{+}$and $\mathrm{TSC} \hat{\circ} \times \mathrm{TSC}+$ progenies from the root apical meristem of seedlings were all diploids $(2 \mathrm{n}=2 \mathrm{x})$ and tetraploids $(2 \mathrm{n}=4 \mathrm{x})$, respectively (Table 3, Fig. 3). Previous studies with tetraploid cultivars of Italian ryegrass showed mixoploids plants can be found by the nonhomogeneous induction of polyploidy with colchicine in diploids plants. In some tissues, chromosomes cannot be duplicated and regenerated, in which the next generations could present a variable chromosomes number range from 14 to 28 (Pereira et al. 2017). However, the results of this research did not demonstrate any mixoploid individual from TSC $\hat{0} \times \mathrm{TSC}_{+}$progenies, suggesting a good selection process during the cultivar development.

The DRR $q \times$ TSC $\bigcirc$ progeny had a lower number of viable seeds, with only 22 metaphases shown good visibility of chromosomes in the magnifying glass (Table 3$)$. These slides, one of 22 seedlings evaluated had triploid chromosomes $(2 \mathrm{n}=3 \mathrm{x})$, whereas all the other seedlings showed diploid chromosomes. Thus, $95 \%$ of progeny from DRR $q \times$ TSC $\hat{~}$ exhibited the same ploidy level found in the female parent (Table 3, Fig. 3). Furthermore, DRR $+\times \operatorname{TSC} \hat{\jmath}$ progeny exhibited high percentage of nonviable seeds, in accordance with the tetrazolium test and embryo absence seen in magnifying glass. Besides, a low triploid seedlings number was found for this crossing. The incompatibility of chromosomal sets to the crosses between plants diploid $\propto \times$ tetraploid ${ }^{\lambda}$ was reported in Italian ryegrass and watermelon, triggering the occurrence of nonviable seeds (Ruchel et al. 2015; Medina et al. 1958). In spite of Italian ryegrass had a greater ratio of cross-pollination ratio, the occurrence of $95 \%$ diploid seedlings can occur due to the small self-fertilization rate, induced in this research when the plants were placed inside growth chambers to pollination and prevent the exchange of external pollen.

Seedlings from DRR $\widehat{O} \times$ TSC $q$ crossing exhibited triploid $(2 \mathrm{n}=3 \mathrm{x})$, tetraploid $(2 \mathrm{n}=4 \mathrm{x})$ and pentaploid $(2 \mathrm{n}=5 \mathrm{x})$ individuals (Table 3, Fig. 3). The authors expected that the seedlings from this crossing could be triploid with three chromosomes copies, but only $10 \%$ of seedlings were characterized as triploids. Triploid descendants of ryegrass can be obtained by emasculation, a reproduction technique used to increase the efficiency (Bustamante et al. 2015). However, this process was not performed for this research because the goal was just to evaluate the natural crossing and risks to transfer the resistance to the next progeny after crossing between a glyphosate-resistant population and susceptible tetraploid plants.

Table 3. Chromosome counting of Italian ryegrass genotypes in crosses involving ploidy levels and glyphosate-resistant diploid genotype.

\begin{tabular}{|c|c|c|c|c|c|}
\hline \multirow{2}{*}{ Crosses } & \multirow{2}{*}{$\begin{array}{c}\text { Metaphases } \\
\text { evaluated }\end{array}$} & \multicolumn{4}{|c|}{ Ploidy level (\%) } \\
\hline & & $2 x$ & $3 x$ & $4 x$ & $5 x$ \\
\hline DRR $\delta \times$ DRR $q$ & 50 & 100 & - & - & - \\
\hline $\mathrm{TSC}_{3} \times \mathrm{TSC}_{+}$ & 50 & - & - & 100 & - \\
\hline $\operatorname{DRR}_{+} \times \operatorname{TSC}^{0}$ & 22 & 95.5 & 4.5 & - & - \\
\hline $\mathrm{DRR}_{\delta} \times \mathrm{TSC}+$ & 50 & - & 10 & 65 & 25 \\
\hline
\end{tabular}

DRR: glyphosate resistant diploid genotype, TSC: glyphosate susceptible genotype. ${ }^{1}$ : male genitor, $q$ : female genitor. 

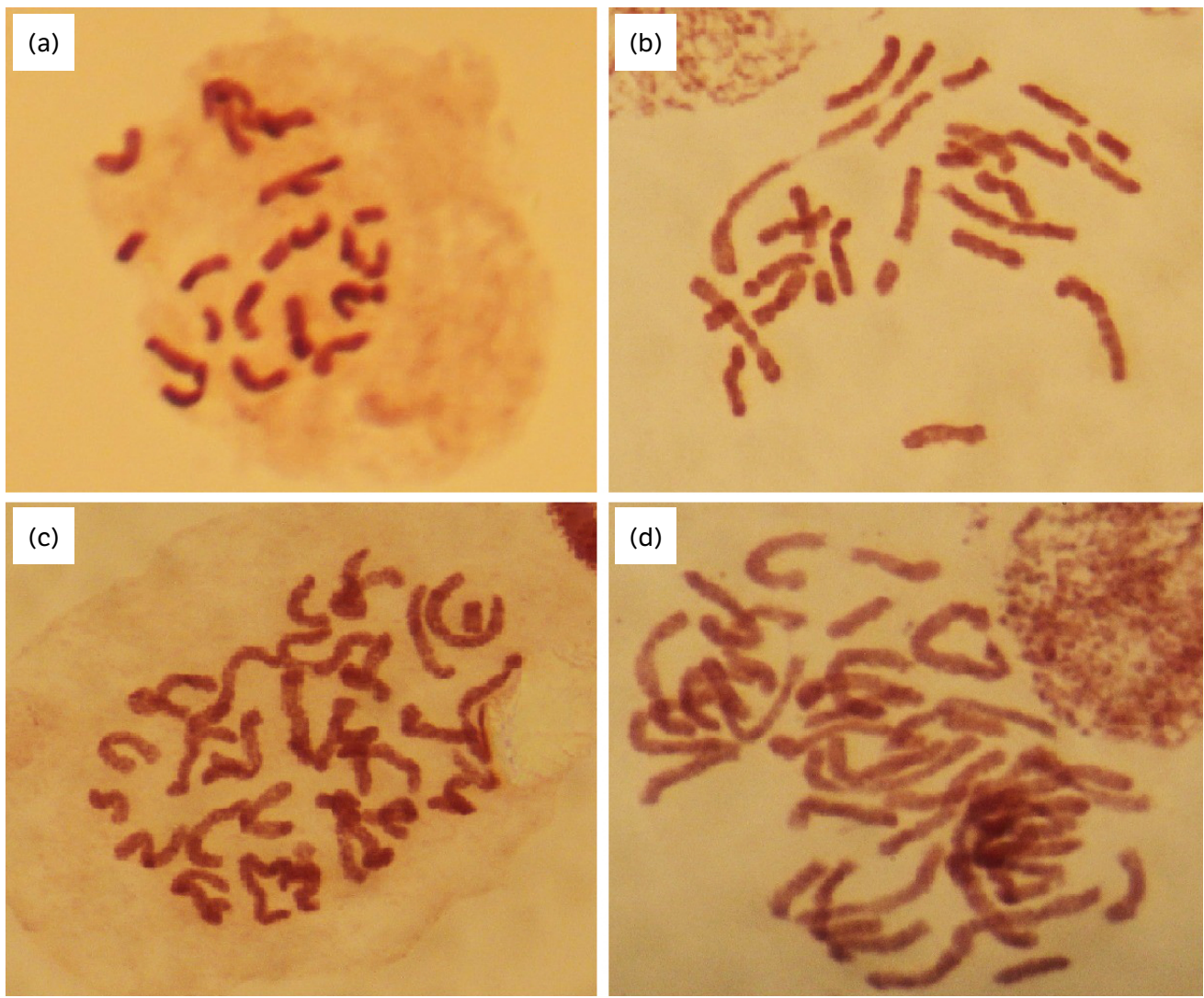

Figure 3. Diploid 2n (a), triploid 3n (b), tetraploid $4 n(c)$ and pentaploid $5 n(d)$ chromosomes of the offspring obtained from the crossing between glyphosate-resistant diploid and tetraploid plants (magnification $\sim 1450 \times$ ).

In the emasculation absence, crosses of diploid Italian ryegrass $\hat{O}$ with three tetraploid cultivars $q$ produced triploid descendants capable of reaching the adult stage, but this behavior only occurred to the seeds harvested from the cultivar Barjumbo (Bustamante et al. 2015). The authors had found one triploid plant produced to each 166 harvested seeds from the tetraploid female parental, equivalent to $0.6 \%$ of total seedlings evaluated. Furthermore, triploid plants showed difficulty to reach the adult stage, with a great number of not germinate seedlings or died further in the vegetative stage of development.

Self-fertilization also was found in DRR $\hat{O} \times$ TSC $q$ progeny, with $65 \%$ of seedlings containing the same ploidy level than the tetraploid female parent. For $25 \%$ of seedlings from this crosses, five copies of chromosomes were reported by the first time to crosses of Italian ryegrass with different ploidy levels. Results from tetraploid plants progeny crossed with diploid fresh-fruit showed variable cellular DNA content, with diploid to pentaploid individuals (Aleza et al. 2012). The regeneration using cell culture in treatments to diploid genotypes of perennial ryegrass and cold storage produced 18 plants with albinism (problems with pigment biosynthesis) and four chimera plants, in which the nuclear DNA content ranged from triploid to pentaploid (Creemers-Molenaar et al. 1992). Thus, low temperatures can act as cell division inhibitors and exhibit similar effects of antimitotics compounds (Pereira et al. 2017).

Results of DRR $\widehat{X} \times$ TSC + progeny had survival problems up to the six-leaf stage. However, Bustamante et al. (2015) did not detect pentaploid plants in the adult plant stage for the progenies from crosses between diploid and tetraploid ryegrass. The main hypothesis to plant death soon after germination can be explained by gene deregulation, losses of functional diversification and sub-functionality due to the changes of ploidy level (Adams and Wendel 2005). Similar response was reported in perennial ryegrass submitted to cold storage, with influence on chromosomal instability and disturbances in gene balance (Creemers-Molenaar et al. 1992).

In general, the F1 progeny from crossing between glyphosate-resistant diploid and tetraploid Italian ryegrass did not transfer resistant alleles to the next generation. The offspring from tetraploid female plants pollinated with glyphosate-resistant 
diploid plants showed survival problems during the early growth stages due to the greater occurrence of triploid and pentaploid individuals. Nevertheless, lower viable seeds were produced by diploid females, in which the segregation pattern to glyphosate resistance was distorted, reducing considerably the number of individuals carrying resistant alleles. Our results suggest the sowing of tetraploid instead diploid ryegrass in fields with glyphosate-resistant populations can be a safe tool to reduce and avoid the frequency of resistant populations to glyphosate.

\section{CONCLUSION}

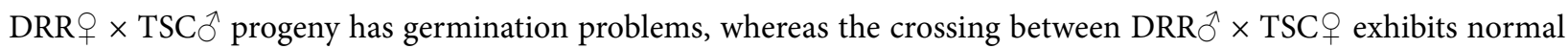
germination, but a greater dead seedling number during the initial development.

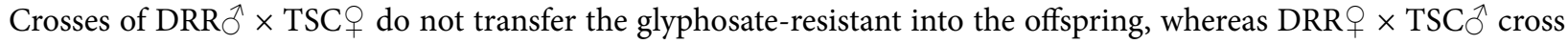
reduces the ratio of descendent carrying the glyphosate-resistant alleles.

\section{FUNDERS}

Coordenação de Aperfeiçoamento de Pessoal de Nível Superior - Finance Code 001

[https://doi.org/10.13039/501100002322]

University of Costa Rica

Embrapa/Bayer project

\section{AUTHOR'S CONTRIBUTION}

Conceptualization, Schmitz M. F., Cechin J., Henckes J. R. and Vargas A. A. M.; Methodology, Schmitz M. F., Agostinetto D., Vargas L., Rocha B. H. G. and Bobrowski V. L.; Investigation, Schmitz M. F., Cechin J., Henckes J. R. and Vargas A. A. M; WritingOriginal Draft, Schmitz M. F. and Cechin J.; Writing - Review and Editing, Schmitz M. F. and Cechin J.; Funding Acquisition, Agostinetto D., Vargas L., Rocha B. H. G. and Bobrowski V. L.; Resources, Agostinetto D. and Vargas L; Supervision, Vargas L.

\section{REFERENCES}

Adams, K. L. and Wendel, J. F. (2005). Polyploidy and genome evolution in plants. Current Opinion in Plant Biology, 8, 135-141. https:// doi.org/10.1016/j.pbi.2005.01.001

Ahloowalia, B. S. (1975). Triploid hybrids between Italian and perennial ryegrass. Euphytica, 24, 413-419. https://doi.org/10.1007/ BF00028208

Aleza, P., Juárez, J., Hernández, M., Ollitrault, P. and Navarro, L. (2012). Implementation of extensive citrus triploid breeding programs based on $4 x \times 2 x$ sexual hybridisations. Tree Genetics \& Genome, 8, 1293-1306. https://doi.org/10.1007/s11295-012-0515-6

[BRAZIL] Ministério da Agricultura, Pecuária e Abastecimento. (2009). Regras para análise de sementes. Brasília: MAPA/ACS. [Accessed Nov. 21, 2019]. Available at: https://www.abrates.org.br/files/regras_analise_de_sementes.pdf 
Bustamante, F. O., Rocha, L. C., Santos, N. S., Silveira, R. A. D., Nunes, R. C., Mittelmann, A. and Techio, V. H. (2015). Analysis of nuclear DNA content and chromosome number for screening genotypes and crosses in annual ryegrass (Lolium multiflorum Lam.). Australian Journal of Crop Science, 9, 666-670.

Creemers-Molenaar, J., Loeffen, J. P. M., van Rossum, M. and Colijn-Hooymans, C. M. (1992). The effect of genotype, cold storage and ploidy level on the morphogenic response of perennial ryegrass (Lolium perenne L.) suspension cultures. Plant Science, 83, 87-94. https://doi.org/10.1016/0168-9452(92)90065-T

Fearon, C. H., Hayward, M. D. and Lawrence, M. J. (1983). Self-incompatibility in ryegrass: V. Genetic control, linkage and seed-set in diploid Lolium multiflorum Lam. Heredity, 50, 35-45. https://doi.org/10.1038/hdy.1983.5

Ferriol, M., Garmendia, A., Gonzalez, A. and Merle, H. (2015). Allogamy-autogamy switch enhance assortative mating in the allotetraploid Centaurea seridis L. coexisting with the diploid Centaurea aspera L. and triggers the asymmetrical formation of triploid hybrids. PLoS ONE, 10, e0140465. https://doi.org/10.1371/journal.pone.0140465

Ghanizadeh, H., Buddenhagen, C. E., Harrington, K. C. and James, T. K. (2019). The genetic inheritance of herbicide resistance in weeds. Critical Reviews in Plant Sciences, 38, 295-312. https://doi.org/10.1080/07352689.2019.1665769

Ghanizadeh, H. and Harrington, K. C. (2018). Restricted glyphosate translocation in Lolium multiflorum is controlled by a single incomplete dominant nuclear gene. New Zealand Journal of Crop and Horticultural Science, 46, 346-353. https://doi.org/10.1080/01 140671.2018.1449124

Jugulam, M., Walsh, M. and Hall, J. C. (2014). Introgression of phenoxy herbicide resistance from Raphanus raphanistrum into Raphanus sativus. Plant Breeding, 133, 489-492. https://doi.org/10.1111/pbr.12168

Lucio, F. R., Kalsing, A., Adegas, F. S., Rossi, C. V. S., Correia, N. M., Gazziero, D. L. P. and Silva, A. F. (2019). Dispersal and frequency of glyphosate-resistant and glyphosate-tolerant weeds in soybean-producing edaphoclimatic microregions in Brazil. Weed Technology, 33, 217-231. https://doi.org/10.1017/wet.2018.97

Medina, D. M., Prado, O. T., Mendes, A. J. T. and Roessing, C. (1958). A poliploidia artificial na obtenção de melancia sem sementes. Bragantia, 17, 81-103. https://doi.org/10.1590/S0006-87051958000100005

Nair, R. M. (2004). Developing tetraploid perennial ryegrass (Lolium perenne L.) populations. New Zealand Journal of Agricultural Research, 47, 45-49. https://doi.org/10.1080/00288233.2004.9513569

Oliveira, L. V., Ferreira, O. G. L., Coelho, R. A. T., Farias, P. P. and Silveira, R. F. (2014). Características produtivas e morfofisiológicas de cultivares de azevém. Pesquisa Agropecuária Tropical, 44, 191-197. https://doi.org/10.1590/S1983-40632014000200011

Pereira, R. C., Davide, L. C., Techio, V. H. and Timbó, A. L. O. (2012). Duplicação cromossômica de gramíneas forrageiras: uma alternativa para programas de melhoramento genético. Ciência Rural, 42, 1278-1285. https://doi.org/10.1590/S0103-84782012000700023

Pereira, R. C., Santos, N. S., Bustamante, F. O., Mittelmann, A. and Techio, V. H. (2017). Stability in chromosome number and DNA content in synthetic tetraploids of Lolium multiflorum after two generations of selection. Ciência Rural, 47, e20150767. https://doi. org/10.1590/0103-8478cr20150767

Ranney, T. G. (2006). Polyploidy: From evolution to new plant development ${ }^{\odot}$. Combined Proceedings International Plant Propagators' Society, 56, 137-142.

Roodt, D., Lohaus, R., Sterck, L., Swanepoel, R. L., Van de Peer, Y. and Mizrachi, E. (2017). Evidence for an ancient whole genome duplication in the cycad lineage. PLoS ONE, 12, e0184454. https://doi.org/10.1371/journal.pone.0184454

Ruchel, Q., Vargas, L., Agostinetto, D., Fernando, J. A., Lüdtke, R. and Bobrowski, V. L. (2015). Caracterização morfoanatômica, contagem cromossômica e viabilidade polínica de biótipos de azevém suscetível e resistentes ao herbicida glyphosate. Planta Daninha, 33, 567578. https://doi.org/10.1590/S0100-83582015000300019 
Schmitz, M. F., Cechin, J., Henckes, J. R., Piasecki, C., Agostinetto, D. and Vargas, L. (2019). Fitness cost and competitive ability to different ploidy levels in ryegrass genotypes. Planta Daninha, 37, e019181921. https://doi.org/10.1590/s0100-83582019370100115

Timbó, A. L. O., Souza, P. N. C., Pereira, R. C., Nunes, J. D., Pinto, J. E. B. P., Souza Sobrinho, F. and Davide, L. C. (2014). Obtaining tetraploid plants of ruzigrass (Brachiaria ruziziensis). Revista Brasileira de Zootecnia, 43, 127-131. https://doi.org/10.1590/S1516-35982014000300004 Tonetto, C. J., Müller, L., Medeiros, S. L. P., Manfron, P. A., Bandeira, A. H., Morais, K. P., Leal, L. T., Milttemann, A. and Dourado Neto, D. (2011). Produção e composição bromatológica de genótipos diplóides e tetraplóides de azevém. Zootecnia Tropical, $29,169-178$.

Van Zanten, M., Liu, Y. and Soppe, W. J. J. (2013). Epigenetic Signalling During the Life of Seeds. In G. Grafi and N. Ohad (Eds), Epigenetic memory and control in plants (p.127-153). Berlin: Springer. https://doi.org/10.1007/978-3-642-35227-0_7

Vargas, L., Moraes, R. M. A. and Berto, C. M. (2007). Herança da resistência de azevém (Lolium multiflorum) ao glyphosate. Planta Daninha, 25, 567-571. https://doi.org/10.1590/S0100-83582007000300016

Vargas, L., Ruchel, Q., Agostinetto, D., Lamego, F. P., Langaro, A. C. and Piesanti, S. R. (2016). Verification of the mechanism of glyphosate resistance in Italian ryegrass biotypes. Planta Daninha, 34, 565-573. https://doi.org/10.1590/s0100-83582016340300017

Wendel, J. F., Jackson, S. A., Meyers, B. C. and Wing, R. A. (2016). Evolution of plant genome architecture. Genome Biology, 17, 1-37. https://doi.org/10.1186/s13059-016-0908-1 